\title{
Postoperative acute kidney injury
}

\author{
Korean Journal of Anesthesiology Jung Tak Park \\ Department of Internal Medicine, Institute of Kidney Disease Research, Yonsei University College of Medicine, \\ Seoul, Korea
}

Acute kidney injury (AKI) after cardiac surgery is a common and serious complication. Several definitions of AKI have been proposed recently, and include both increases in serum creatinine levels and decreases in urine output as diagnostic criteria. The pathophysiology of postoperative AKI is complex and involves both ischemic injury and systemic inflammation. Identifying risk factors, such as old age, underlying diabetes, heart failure, and obesity, may aid in the application of preventative methods for postoperative AKI. Additionally, recognizing different risks after different types of surgical procedures would be valuable. Novel biomarkers that could detect AKI more precisely at an earlier time point are being investigated. Several new biomarkers have been assessed in large multi-center studies and are believed to accommodate conventional clinical findings in diagnosing postoperative AKI. In high-risk patients, preventative measures, such as the maintenance of adequate hemodynamics and sufficient fluid resuscitation, could lower the incidence of postoperative AKI. Avoiding nephrotoxic agents and optimizing preoperative hemoglobin levels to avoid excessive transfusions would also be beneficial. In situations in which medical management fails to maintain sufficient urine output and acid-base and electrolyte homeostasis, early initiation of renal replacement therapy should be considered.

Key Words: Acute kidney injury, Postoperative complications, Renal protection, Surgery.

\section{Introduction}

Acute kidney injury (AKI), a condition characterized by persistent oliguria and elevated serum creatinine levels, is a common complication in patients undergoing surgery. The incidence of AKI varies from $5.0-7.5 \%$ in hospitalized patients receiving acute care, and can reach up to $20 \%$ in patients in the intensive care unit $[1,2]$. Although the incidence of postoperative AKI depends greatly on the type of surgery, overall, $40 \%$ of in-hospital AKI cases are related to surgical procedures [3]. Reported incidence rates of AKI associated with cardiac surgery

Corresponding author: Jung Tak Park, M.D., Ph.D.

Department of Internal Medicine, Severance Hospital, Yonsei University College of Medicine, 50, Yonsei-ro, Seodaemun-gu, Seoul 03722, Korea

Tel: 82-2-2228-1978, Fax: 82-2-393-6884

Email: JTPARK@yuhs.ac

Received: April 26, 2017.

Revised: May 4, 2017.

Accepted: May 8, 2017.

Korean J Anesthesiol 2017 June 70(3): 258-266

https://doi.org/10.4097/kjae.2017.70.3.258 range from $7.7-40 \%$, depending on the patient population [4-8]. Improvements in surgical procedures and perioperative management have increased the number of surgical patients with severe comorbidities and older age, which has led to an increase in patients who are at a high risk of postoperative complications, such as infections, gastrointestinal dysfunction, acute lung injury, and postoperative AKI. Recent investigations have shown that postoperative AKI increases the risk of morbidity after surgery and in-hospital mortality [6,9-11]. Patients who develop postoperative AKI have been found to develop sepsis and coagulopathy more often than those who do not develop postoperative AKI [12]. Additionally, patients with postoperative AKI are at higher risk of needing mechanical ventilation [12]. Moreover, a recent study found that the mortality rate at 30 days after intraabdominal surgery was 15 -fold higher in patients with AKI than in those without, indicating that the risk of mortality is higher in patients with AKI even after the recovery of renal function [13].

This review discusses the definition and pathophysiology of postoperative AKI and explores current methods of identifying postoperative AKI, including the role of novel biomarkers. Finally, it provides recommendations for preventative measures and management strategies.

(c) This is an open-access article distributed under the terms of the Creative Commons Attribution Non-Commercial License (http://creativecommons.org/ licenses/by-nc/4.0/), which permits unrestricted non-commercial use, distribution, and reproduction in any medium, provided the original work is properly cited. 


\section{Definition of AKI}

Various definitions have been applied to effectively determine the extent of renal function decline that affects patient morbidity and mortality. The glomerular filtration rate (GFR) is the most accurate representation of renal function. However, estimating the GFR using a 24-h urine creatinine clearance test is troublesome and time-consuming in acute situations when immediate treatment decisions are needed. Thus, most recent definitions use urine output and serum creatinine levels as surrogates of renal function because of their easy-to-measure characteristics.

The first consensus on the definition of AKI, the Risk, Injury, Failure, Loss and End-stage Kidney (RIFLE) criteria, was reported in 2004 by the Acute Dialysis Quality Initiative [14]. The RIFLE system classifies AKI into three stages of severity, determined by serum creatinine levels or changes in urine output, and two outcome stages, decided by the duration of kidney function loss. This system also introduced the term 'AKI' to replace the formerly used term 'acute renal failure.' This change in terminology reflects the fact that structural injury to the kidney precedes the loss of kidney function, highlighting the importance of salvaging actions even before actual failure of function occurs.

In 2007, the RIFLE system was revised by the Acute Kidney Injury Network (AKIN) [15]. With increasing evidence showing that even small elevations in serum creatinine levels may be associated with increases in morbidity and mortality [16], the AKIN system allows the definition of AKI without knowledge of baseline serum creatinine levels.
Studies comparing these two classification systems have shown that both definitions can effectively identify AKI within the first $24 \mathrm{~h}[17,18]$. Additionally, the severity of AKI clearly predicts clinical outcomes in both systems [19]. However, overdiagnosis can occur when AKI is defined solely on the basis of the degree of serum creatinine change [19]. Choosing the appropriate baseline creatinine level for comparison is key in these situations.

The most recent consensus on the definition and staging of AKI was reached in 2012 by the Kidney Disease: Improving Global Outcomes (KDIGO) Foundation [20]. It defined AKI as any of the following: an increase in serum creatinine by $\geq$ $0.3 \mathrm{mg} / \mathrm{dl}(\geq 26.5 \mu \mathrm{mol} / \mathrm{L})$ within $48 \mathrm{~h}$; or an increase in serum creatinine to $\geq 1.5$ times the baseline value, which is known or presumed to have occurred within the prior 7 days; or urine volume $<0.5 \mathrm{ml} / \mathrm{kg} / \mathrm{h}$ for $6 \mathrm{~h}$. In particular, the KDIGO criteria eliminated the use of GFR and added a timeframe according to the absolute level or relative increase of serum creatinine. Additionally, this system added a new class to recognize patients with acute kidney damage superimposed on an underlying chronic kidney disease. Moreover, KDIGO recommends staging AKI according to severity, based on investigations demonstrating that mortality and renal replacement therapy risks increase with each stage [21]. Table 1 compares the three different definition criteria.

Despite these efforts to detect AKI effectively and in a timely manner, definitions that include serum creatinine levels still have limitations. Most importantly, serum creatinine levels begin to increase after the pathological changes of kidney injury

Table 1. Comparison of the Three Classifications and Staging of AKI

\begin{tabular}{|c|c|c|c|}
\hline Classification & RIFLE & AKIN & KDIGO \\
\hline \multirow[t]{10}{*}{ Stage } & Risk & Stage 1 & Stage 1 \\
\hline & $\begin{array}{l}\text { Increased } \mathrm{sCr} \times 1.5 \text { or GFR decrease } \\
>25 \% \text { or urine output }<0.5 \mathrm{ml} / \mathrm{kg} / \mathrm{h} \\
\text { for } 6 \mathrm{~h}\end{array}$ & $\begin{array}{l}\text { Increased } \mathrm{sCr} \times 1.5 \text { or } \geq 0.3 \mathrm{mg} / \mathrm{dl} \\
\text { from baseline or urine output } \\
<0.5 \mathrm{ml} / \mathrm{kg} / \mathrm{h} \text { for } 6 \mathrm{~h}\end{array}$ & $\begin{array}{l}\text { Increased } \mathrm{sCr} \times 1.5 \text { to } 1.9 \text { baseline or } \\
\geq 0.3 \mathrm{mg} / \mathrm{dl} \text { from baseline or urine } \\
\text { output }<0.5 \mathrm{ml} / \mathrm{kg} / \mathrm{h} \text { for } 6 \text { to } 12 \mathrm{~h}\end{array}$ \\
\hline & Injury & Stage 2 & Stage 2 \\
\hline & $\begin{array}{l}\text { Increased } \mathrm{sCr} \times 2 \text { or GFR decrease } \\
>50 \% \text { or urine output }<0.5 \mathrm{ml} / \mathrm{kg} / \mathrm{h} \\
\text { for } 12 \mathrm{~h}\end{array}$ & $\begin{array}{l}\text { Increased } \mathrm{sCr} \times 2 \text { or urine output } \\
<0.5 \mathrm{ml} / \mathrm{kg} / \mathrm{h} \text { for } 12 \mathrm{~h}\end{array}$ & $\begin{array}{l}\text { Increased } \mathrm{sCr} \times 2.0 \text { to } 2.9 \text { baseline or } \\
\text { urine output }<0.5 \mathrm{ml} / \mathrm{kg} / \mathrm{h} \text { for } 12 \mathrm{~h}\end{array}$ \\
\hline & Failure & Stage 3 & Stage 3 \\
\hline & $\begin{array}{l}\text { Increased } \mathrm{sCr} \times 3 \text { or GFR decrease } \\
>75 \% \text { or } \mathrm{sCr} \geq 4 \mathrm{mg} / \mathrm{dl} \text { (acute rise of } \\
\mathrm{sCr} \geq 0.5 \mathrm{mg} / \mathrm{dl} \text { ) or urine output } \\
<0.3 \mathrm{ml} / \mathrm{kg} / \mathrm{h} \text { for } 24 \mathrm{~h} \text { or anuria for } 12 \mathrm{~h}\end{array}$ & $\begin{array}{l}\text { Increased } \mathrm{sCr} \times 3 \text { or } \geq 4 \mathrm{mg} / \mathrm{dl} \text { with } \\
\text { acute rise of } \mathrm{sCr} \geq 0.5 \mathrm{mg} / \mathrm{dl} \text { or } \\
\text { urine output }<0.3 \mathrm{ml} / \mathrm{kg} / \mathrm{h} \text { for } 24 \mathrm{~h} \text { or } \\
\text { anuria for } 12 \mathrm{~h}\end{array}$ & $\begin{array}{l}\text { Increased } \mathrm{sCr} \times 3 \text { baseline or } \geq 4 \mathrm{mg} / \mathrm{dl} \\
\text { or initiation of RRT, or GFR decrease } \\
<35 \mathrm{ml} / \mathrm{min} / 1.73 \mathrm{~m}^{2} \text { for patients } \\
<18 \text { years of age or urine output } \\
<0.3 \mathrm{ml} / \mathrm{kg} / \mathrm{h} \text { for } 24 \mathrm{~h} \text { or anuria for } 12 \mathrm{~h}\end{array}$ \\
\hline & Loss & & \\
\hline & Persistent AKI > 4 weeks & & \\
\hline & ESRD & & \\
\hline & End-stage renal disease & & \\
\hline
\end{tabular}

RIFLE: Risk, Injury, Failure, Loss and End-stage Kidney, AKIN: Acute Kidney Injury Network, KDIGO: Kidney Disease: Improving Global Outcomes, sCr: serum creatinine level, GFR: glomerular filtration rate, AKI: acute kidney injury, ESRD: end-stage renal disease. 
are already well established. Thus, timely measures to prevent the progression of kidney injury at an early time point may not be possible. Additionally, the serum creatinine level is affected by volume status, infectious conditions, steroid use, and muscle mass [22]. Therefore, recent investigations have focused on developing biomarkers that can effectively detect AKI at earlier time points.

\section{Pathophysiology}

Traditionally, the causes of AKI have been classified into prerenal, intrinsic, and postrenal factors. These classifications provide practical information about the underlying pathophysiology of the etiology of AKI, but to date the causes of AKI have not been differentiated clearly in a clinical setting. When the duration of AKI induced by a prerenal cause is prolonged, renal parenchymal damage progresses, eventually giving rise to intrinsic kidney injury [22].

Prerenal AKI occurs when the perfusion of the kidney is altered. The kidney, which has the highest tissue perfusion rate relative to organ weight, normally receives $15-20 \%$ of total cardiac output [23]. This high perfusion rate makes the kidney vulnerable to hemodynamic injury. Prerenal AKI is found most commonly in patients undergoing cardiac surgery who have undergone cardiopulmonary bypass procedures [24,25]. However, recent investigations have shown that in addition to hemodynamic alterations, inflammation and direct nephrotoxic effects on tubular cells play crucial roles in inducing AKI in patients after cardiac surgery [26]. Additionally, factors not related to the surgical procedure itself, such as the presence of valvular disease, inotropic use, or postoperative intra-aortic balloon pump support, can reduce renal blood flow, subsequently aggravating the damage caused by cardiopulmonary bypass. Moreover, impaired glomerular hemodynamics resulting from the use of non-steroidal anti-inflammatory drugs, diuretics, and renin-angiotensinaldosterone system blockades may further exacerbate renal damage.

Intrinsic AKI accompanies injury of the major structural components of the kidney. Embolic events and vasculopathies caused by malignant hypertension or microangiopathies induce damage to the renal vasculature. Allergic reactions to medications or infectious organisms can generate renal interstitial injury. Damage to the renal tubules can occur due to profound hemodynamic deterioration in the kidney, or nephrotoxic substances, such as antibiotics or contrast media. Tubular damage is the most common underlying cause of intrinsic AKI occurring after surgery [20]. However, all of the events mentioned above can occur postoperatively. Table 2 summarizes the common etiologies of postoperative AKI.

\section{Risk Factors}

Several factors are known to contribute to postoperative AKI. Identifying these factors could aid in avoiding nephrotoxic drugs and providing close monitoring for renal derangements in high-risk patients.

\section{Comorbidities}

Demographic factors, such as age and gender, have been found to be closely related with the development of postoperative AKI. The capacity of the kidney to adapt to hemodynamic changes declines with age [27]. Not only is renal plasma flow lower, but renal responses to vasodilating factors are also weaker in older patients [28]. Additionally, older patients are more often exposed to medications that can affect renal function, such as diuretics and contrast media. In a recent prospective evaluation of 9,400 patients, female gender was also noted as a significant risk factor for postoperative AKI [29].

Underlying medical conditions, such as chronic kidney disease, diabetes mellitus, hypertension, cardiovascular disease, liver disease, and chronic obstructive pulmonary disease, are welldocumented risk factors predisposing a patient to postoperative AKI $[5,11,27,30,31]$. In a prospective evaluation of 43,642 patients undergoing cardiac surgery, the risk of postoperative AKI was increased significantly among patients with cardiomegaly (odds ratio, $\mathrm{OR}=1.74 ; 95 \% \mathrm{CI}=1.43-2.12$ ), cerebrovascular disease $(\mathrm{OR}=1.89 ; 95 \% \mathrm{CI}=1.48-2.41)$, chronic obstructive

Table 2. Factors Associated with Postoperative AKI

\begin{tabular}{lll}
\hline \multicolumn{1}{c}{ Preoperative } & \multicolumn{1}{c}{ Intraoperative } & Postoperative \\
\hline Nephrotoxic drugs & Cardiopulmonary bypass & Decreased cardiac function \\
Inflammation & Anemia & Vasoactive drugs \\
Underlying CKD & Shock & Nephrotoxic drugs \\
Decreased effective volume & Hemodilution & Inflammation \\
Renovascular disease & Embolic events & Unstable hemodynamic state \\
Congestive heart failure & & \\
\hline
\end{tabular}

AKI: acute kidney injury, CKD: chronic kidney disease. 
pulmonary disease $(\mathrm{OR}=1.55 ; 95 \% \mathrm{CI}=1.28-1.88)$, diabetes mellitus $(\mathrm{OR}=1.43$; 95\% CI $=1.08-1.89)$, and New York Heart Association class IV status $(\mathrm{OR}=2.12 ; 95 \% \mathrm{CI}=1.78-2.54)$. However, the risk of AKI was unrelated to remote myocardial infarction or a history of percutaneous coronary artery angioplasty [5].

\section{Obesity}

Obesity, particularly severe obesity, defined by a body mass index (BMI) of $>40 \mathrm{~kg} / \mathrm{m}^{2}$, is associated with a higher risk of postoperative AKI than lower BMI [32,33]. The reason for this increased risk is known to be related to the changes in renal hemodynamics induced by adipose tissue in obese patients [34,35]. The type and location of adipose tissue is also suspected to affect renal function after surgery. In a recent investigation, abdominal obesity, quantified using computed tomography scans, was particularly associated with postoperative AKI [36].

\section{Metabolic acidosis}

A recent investigation evaluating factors associated with AKI development after cardiac surgery revealed that low preoperative serum bicarbonate levels $(<23 \mathrm{mEq} / \mathrm{L})$ were independently associated with a two-fold increased risk of postoperative AKI [37]. The underlying mechanism for the association between low serum bicarbonate concentrations and postoperative AKI is unclear, but several possibilities can be considered on the basis of previous animal experiments. Metabolic acidosis is known to induce medullary ammonia production, which in turn activates the alternative complement pathway and aggravates tubular inflammation in an animal model of AKI [38]. Additionally, excessive acid loading in mice resulted in activation of the intrarenal renin-angiotensin-aldosterone system [39]. Moreover, sodium bicarbonate is known to increase renal medullary oxygen delivery and to reduce renal iron-mediated free radical formation [40]. Based on these findings, some investigators have attempted to prevent AKI through urine alkalization by means of sodium bicarbonate infusion; however, the results of these trials have been inconsistent $[41,42]$.

\section{Type of surgery}

The type of surgery has a significant effect on the risk of postoperative AKI occurrence. The risk of postoperative AKI is increased in emergency surgery versus elective operations $[30,31]$. Compared with other surgical procedures, intraperitoneal surgery, especially exploratory laparotomy and small-bowel resection operations, is known to increase the risk of postoperative AKI $[31,43,44]$. Increased intra-abdominal pressure, caused by excessive fluid administration in these operations, results in a situation in which the intra-abdominal pressure compresses the renal veins and constricts the renal arteries, activating the sympathetic system; this is known as abdominal compartment syndrome [45-47]. This condition ultimately leads to a reduction in renal perfusion and can cause ischemic damage to the kidneys [45]. Similarly, urine output decreases during a laparoscopy due to increased abdominal pressure resulting from intraabdominal gas insufflation [48]. However, the reduction in urine output during laparoscopy has not been found to increase the risk of postoperative AKI $[49,50]$. Nonetheless, increasing intraabdominal pressure should be avoided in older and high-risk patients, such as those with underlying CKD.

Major vascular surgery and cardiac operations also increase the risk of postoperative AKI in particular $[8,51]$. Previous studies have demonstrated that AKI occurs in almost 30\% of patients who have undergone cardiac surgery, although the incidence of AKI associated with cardiac surgery varies somewhat depending on the characteristics of the study population [8,19,51]. Although several pathophysiological factors have been identified, such as ischemic-reperfusion injury, inflammation, microembolism, decreased renal perfusion, and the use of nephrotoxic drugs, the mechanism of the increased postoperative AKI risk in patients undergoing cardiac operation is not yet fully understood [52]. The type of cardiac operation is also linked to different effects in inducing postoperative AKI. Because cardiopulmonary bypass per se is a known risk factor for AKI, coronary artery bypass graft (CABG) operations using cardiopulmonary bypass were associated with a higher incidence of AKI compared with off-pump CABG [24,25]. Patients receiving cardiac valve surgery also have higher incidences of postoperative AKI than those undergoing on-pump CABG operations [24,25,53].

\section{Drugs}

Preoperative and intraoperative uses of medications have been evaluated extensively as a cause of postoperative AKI. Medications that block the renin-angiotensin-aldosterone system and non-steroidal anti-inflammatory drugs increase the risk of postoperative AKI [54,55]. The influence on the compensatory mechanism that maintains the GFR under hemodynamically compromised conditions is the main mechanism for this increased risk. Aminoglycosides induce renal damage via mitochondrial dysfunction [35]. The combination of two or more nephrotoxic drugs, consisting of diuretics with angiotensin-converting enzyme inhibitors or angiotensin receptor blockers and non-steroidal anti-inflammatory drugs, was found to increase the risk of AKI considerably in an evaluation of a large cohort of patients with hypertension [54].

Patients who undergo radiological examinations involving 
contrast media before surgery are at an increased risk of developing postoperative AKI [56]. The mechanism of contrastinduced nephropathy is not understood, but it is believed to include direct damage from reactive oxygen species $[57,58]$. Because hypovolemia aggravates the renal damage induced by contrast media, it is important to maintain effective blood volume in patients exposed to contrast media before surgery.

\section{Biomarkers}

Detecting AKI by using serum creatinine levels is problematic because serum creatinine levels are elevated after renal function has declined, and do not reflect injury. Therefore, recent investigations have focused on finding practical serum and urine biomarkers that could reveal early injury before profound functional damage occurs.

Neutrophil gelatinase-associated lipocalin (NGAL) is released from neutrophils and is induced by inflammation. Studies have shown that elevated urine and serum NGAL levels reflect tubular injury $[59,60]$. In a study of children undergoing cardiopulmonary bypass, urine concentrations of NGAL increased $2 \mathrm{~h}$ after cardiopulmonary bypass, whereas AKI diagnosis with serum creatinine was only possible 1-3 days after the procedure. In this study, the amount of NGAL in urine at $2 \mathrm{~h}$ after cardiopulmonary bypass was the most powerful independent predictor of acute renal injury [61]. However, because NGAL is produced throughout the body, it is difficult to distinguish systemic inflammation from localized renal inflammation with elevated levels of NGAL [62]. This limitation has restricted the use of NGAL in detecting AKI. Cystatin C (CyC) is a protease inhibitor produced by nucleated cells at a constant rate. This is filtered freely by the glomerulus and reabsorbed completely by the renal tubules. CyC is not normally found in urine, so detection of CyC in urine may indicate renal injury $[63,64]$. Kidney injury molecule-1 (KIM-1) is highly upregulated in proximal tubular cells after kidney injury. A recent study reported that plasma KIM-1 levels increased within 2 days after surgery only in patients who developed AKI, suggesting KIM-1 as a biomarker capable of early AKI detection [65].

Recently, some researchers have assessed combinations of two or more biomarkers to improve the diagnostic power for AKI. This approach is promising in that different biomarkers indicate different aspects of renal injury. In a prospective evaluation of 90 patients undergoing cardiac surgery, Han et al. [66] reported that the combination of urinary KIM-1, $N$-acetyl-betaD-glucosaminidase, and NGAL enhanced the sensitivity of early detection of postoperative AKI compared with individual biomarkers.

Tissue inhibitor of metalloproteinase-2 (TIMP-2) and insulin-like growth factor binding protein 7 (IGFBP7) are cell-cycle arrest proteins. In events of tubular injury due to toxin exposure, hypoxia, and inflammation, these proteins are released into the urine [67]. Recent multi-center studies have demonstrated that TIMP-2 and IGFBP7 are superior to existing markers, and provide additional information in detecting AKI to that provided by clinical variables $[68,69]$. The US Food and Drug Administration recently approved the combination of these two novel urinary biomarkers to assess the risk of AKI in critically ill patients.

\section{Therapeutic Approach}

Maintaining adequate hemodynamics to prevent tissue hypoperfusion and renal ischemic injury is the primary goal of perioperative management [70]. Blood pressure is a practical surrogate indicating hemodynamic status. Prolonged periods of perioperative hypotension have been found to be significantly associated with postoperative AKI. An investigation evaluating the perioperative data of 33,330 patients undergoing noncardiac surgery revealed that $1-5 \mathrm{~min}$ of an intraoperative mean arterial pressure of $<55 \mathrm{mmHg}$ was significantly associated with the development of postoperative AKI [71].

Adequate fluid management is a key component in maintaining intravascular volume and cardiac hemodynamics in patients undergoing surgery. However, although under resuscitation increases the risk of renal hypoperfusion, excessive fluid administration is capable of decreasing renal blood flow and GFR by increasing renal subcapsular pressure and inducing abdominal compartment syndrome [72]. Recent non-invasive methods for monitoring hydration status, such as chest ultrasound for detecting pulmonary congestion and body composition monitoring through bioimpedance spectroscopy techniques, may help to maintain appropriate hydration status $[73,74]$.

The type of fluid used for volume resuscitation also affects postoperative renal function. Because normal saline actually contains supraphysiological levels of chloride, infusion of large volumes of normal saline may cause hyperchloremic acidosis, which can lead to a decrease in renal perfusion. Animal studies have shown that hyperchloremia produces progressive renal vasoconstriction and decreases in GFR [75]. In an investigation comparing the effects of intravenous administration of normal saline and a balanced crystalloid solution, only normal saline resulted in a reduction in renal cortical tissue perfusion [76].

Anemia induces renal medullary hypoxia, which is one of the key mechanisms leading to AKI [77]. In an observational study of patients undergoing non-cardiac surgery, low preoperative and early postoperative decreases in hemoglobin concentrations were strongly associated with postoperative AKI in a graded manner [78]. Additionally, intraoperative transfusions have been found to increase the risk of postoperative AKI development. An investigation of a cohort of patients who underwent cardiac 
surgery with cardiopulmonary bypass revealed that AKI rates increased in direct proportion to the amount of erythrocytes transfused, and this increase was more pronounced in patients with anemia [79]. It is uncertain whether anemia induced renal hypoxia, or whether toxic effects of transfusion itself increased the risk of postoperative AKI in these patients. Considering that stored red blood cells undergo irreversible changes, making them more adherent to the vascular endothelium, resulting in a decrease in microvascular flow, both low hemoglobin levels and increased amounts of transfusions could play a role in inducing postoperative AKI $[80,81]$. Thus, optimizing the preoperative hemoglobin levels as suggested by the recent 'patient blood management protocol' would be helpful in lowering the risk of postoperative AKI [82].

Once oliguria occurs, interventions improving renal hemodynamics, such as maintaining vascular contractility with inotropes and optimizing heart rate, should be implemented to maintain urine volume. However, if oliguria persists despite these actions, diuretics should be used to maintain urine output. Nonetheless, it should be noted that a recent meta-analysis found that although the use of furosemide may be beneficial in achieving fluid balance, it did not reduce mortality in patients with AKI [83]. Additionally, furosemide can aggravate renal failure by inducing prerenal injury in patients with reduced effective volume.

Renal replacement therapy should be considered when the effort to maintain renal function has failed. The general indications for renal replacement therapy are volume overload, hyperkalemia, and medically unresolved metabolic acidosis. However, early initiation of renal replacement therapy may be beneficial in some cases. In a recent investigation of patients who developed severe AKI after cardiac surgery, early and aggressive continuous venovenous hemofiltration was associated with better-thanpredicted survival $[84,85]$.

\section{Conclusions}

AKI is a common complication in patients undergoing surgery. The clinical significance of postoperative AKI is substantial in that the incidence is growing with the increase in operations in older and severely comorbid patients. Additionally, the development of postoperative AKI increases mortality risks significantly, lengthens hospital stays, and worsens long-term morbidity. The recent definitions and classifications of AKI were intended to provide effective and timely detection of AKI. Nonetheless, assessments based on serum creatinine levels have limitations. The development of novel biomarkers may provide a more accurate and faster way of detecting postoperative AKI, which could eventually lead to earlier intervention. Additionally, recognizing the risk factors of postoperative AKI and understanding the management options would be beneficial in preventing postoperative AKI and improving patient outcomes.

\section{References}

1. Thakar CV, Christianson A, Freyberg R, Almenoff P, Render ML. Incidence and outcomes of acute kidney injury in intensive care units: a Veterans Administration study. Crit Care Med 2009; 37: 2552-8.

2. Uchino S, Kellum JA, Bellomo R, Doig GS, Morimatsu H, Morgera S, et al. Acute renal failure in critically ill patients: a multinational, multicenter study. JAMA 2005; 294: 813-8.

3. Thakar CV. Perioperative acute kidney injury. Adv Chronic Kidney Dis 2013; 20: 67-75.

4. Antunes PE, Prieto D, Ferrão de Oliveira J, Antunes MJ. Renal dysfunction after myocardial revascularization. Eur J Cardiothorac Surg 2004; 25: 597-604.

5. Chertow GM, Lazarus JM, Christiansen CL, Cook EF, Hammermeister KE, Grover F, et al. Preoperative renal risk stratification. Circulation 1997; 95: 878-84.

6. Chertow GM, Levy EM, Hammermeister KE, Grover F, Daley J. Independent association between acute renal failure and mortality following cardiac surgery. Am J Med 1998; 104: 343-8.

7. Ostermann ME, Taube D, Morgan CJ, Evans TW. Acute renal failure following cardiopulmonary bypass: a changing picture. Intensive Care Med 2000; 26: 565-71.

8. Rosner MH, Okusa MD. Acute kidney injury associated with cardiac surgery. Clin J Am Soc Nephrol 2006; 1: 19-32.

9. Mangano CM, Diamondstone LS, Ramsay JG, Aggarwal A, Herskowitz A, Mangano DT. Renal dysfunction after myocardial revascularization: risk factors, adverse outcomes, and hospital resource utilization. The Multicenter Study of Perioperative Ischemia Research Group. Ann Intern Med 1998; 128: 194-203.

10. Thakar CV, Liangos O, Yared JP, Nelson D, Piedmonte MR, Hariachar S, et al. ARF after open-heart surgery: Influence of gender and race. Am J Kidney Dis 2003; 41: 742-51.

11. Biteker M, Dayan A, Tekkeşin Aİ, Can MM, Taycı İ, İlhan E, et al. Incidence, risk factors, and outcomes of perioperative acute kidney injury in noncardiac and nonvascular surgery. Am J Surg 2014; 207: 53-9.

12. Bihorac A, Yavas S, Subbiah S, Hobson CE, Schold JD, Gabrielli A, et al. Long-term risk of mortality and acute kidney injury during 
hospitalization after major surgery. Ann Surg 2009; 249: 851-8.

13. Klionsky DJ, Abdelmohsen K, Abe A, Abedin MJ, Abeliovich H, Acevedo Arozena A, et al. Guidelines for the use and interpretation of assays for monitoring autophagy (3rd edition). Autophagy 2016; 12: 1-222.

14. Bellomo R, Ronco C, Kellum JA, Mehta RL, Palevsky P. Acute renal failure - definition, outcome measures, animal models, fluid therapy and information technology needs: the Second International Consensus Conference of the Acute Dialysis Quality Initiative (ADQI) Group. Crit Care 2004; 8: R204-12.

15. Mehta RL, Kellum JA, Shah SV, Molitoris BA, Ronco C, Warnock DG, et al. Acute Kidney Injury Network: report of an initiative to improve outcomes in acute kidney injury. Crit Care 2007; 11: R31.

16. Chertow GM, Burdick E, Honour M, Bonventre JV, Bates DW. Acute kidney injury, mortality, length of stay, and costs in hospitalized patients. J Am Soc Nephrol 2005; 16: 3365-70.

17. Bagshaw SM, George C, Bellomo R. A comparison of the RIFLE and AKIN criteria for acute kidney injury in critically ill patients. Nephrol Dial Transplant 2008; 23: 1569-74.

18. Bang JY, Lee JB, Yoon Y, Seo HS, Song JG, Hwang GS. Acute kidney injury after infrarenal abdominal aortic aneurysm surgery: a comparison of AKIN and RIFLE criteria for risk prediction. Br J Anaesth 2014; 113: 993-1000.

19. Englberger L, Suri RM, Li Z, Casey ET, Daly RC, Dearani JA, et al. Clinical accuracy of RIFLE and Acute Kidney Injury Network (AKIN) criteria for acute kidney injury in patients undergoing cardiac surgery. Crit Care 2011; 15: R16.

20. Section 2: AKI Definition. Kidney Int Suppl (2011) 2012; 2: 19-36.

21. Kellum JA, Lameire N. Diagnosis, evaluation, and management of acute kidney injury: a KDIGO summary (Part 1). Crit Care 2013; 17: 204.

22. Bellomo R, Kellum JA, Ronco C. Acute kidney injury. Lancet 2012; 380: 756-66.

23. Sear JW. Kidney dysfunction in the postoperative period. Br J Anaesth 2005; 95: 20-32.

24. Hix JK, Thakar CV, Katz EM, Yared JP, Sabik J, Paganini EP. Effect of off-pump coronary artery bypass graft surgery on postoperative acute kidney injury and mortality. Crit Care Med 2006; 34: 2979-83.

25. Wijeysundera DN, Beattie WS, Djaiani G, Rao V, Borger MA, Karkouti K, et al. Off-pump coronary artery surgery for reducing mortality and morbidity: meta-analysis of randomized and observational studies. J Am Coll Cardiol 2005; 46: 872-82.

26. Prowle JR, Bellomo R. Sepsis-associated acute kidney injury: macrohemodynamic and microhemodynamic alterations in the renal circulation. Semin Nephrol 2015; 35: 64-74.

27. Pascual J, Liaño F, Ortuño J. The elderly patient with acute renal failure. J Am Soc Nephrol 1995; 6: 144-53.

28. Fuiano G, Sund S, Mazza G, Rosa M, Caglioti A, Gallo G, et al. Renal hemodynamic response to maximal vasodilating stimulus in healthy older subjects. Kidney Int 2001; 59: 1052-8.

29. Mitter N, Shah A, Yuh D, Dodd-O J, Thompson RE, Cameron D, et al. Renal injury is associated with operative mortality after cardiac surgery for women and men. J Thorac Cardiovasc Surg 2010; 140: 1367-73.

30. Kheterpal S, Tremper KK, Heung M, Rosenberg AL, Englesbe M, Shanks AM, et al. Development and validation of an acute kidney injury risk index for patients undergoing general surgery: results from a national data set. Anesthesiology 2009; 110: 505-15.

31. Kim M, Brady JE, Li G. Variations in the risk of acute kidney injury across intraabdominal surgery procedures. Anesth Analg 2014; 119: 1121-32.

32. Kumar AB, Bridget Zimmerman M, Suneja M. Obesity and post-cardiopulmonary bypass-associated acute kidney injury: a single-center retrospective analysis. J Cardiothorac Vasc Anesth 2014; 28: 551-6.

33. Wigfield CH, Lindsey JD, Muñoz A, Chopra PS, Edwards NM, Love RB. Is extreme obesity a risk factor for cardiac surgery? An analysis of patients with a BMI > or = 40. Eur J Cardiothorac Surg 2006; 29: 434-40.

34. Kwakernaak AJ, Toering TJ, Navis G. Body mass index and body fat distribution as renal risk factors: a focus on the role of renal haemodynamics. Nephrol Dial Transplant 2013; 28 Suppl 4: iv42-9.

35. Suneja M, Kumar AB. Obesity and perioperative acute kidney injury: a focused review. J Crit Care 2014; 29: 694.e1-6.

36. Shashaty MG, Kalkan E, Bellamy SL, Reilly JP, Holena DN, Cummins K, et al. Computed tomography-defined abdominal adiposity is associated with acute kidney injury in critically ill trauma patients*. Crit Care Med 2014; 42: 1619-28.

37. Jung SY, Park JT, Kwon YE, Kim HW, Ryu GW, Lee SA, et al. Preoperative low serum bicarbonate levels predict acute kidney injury after cardiac surgery. Medicine (Baltimore) 2016; 95: e3216.

38. Nath KA, Hostetter MK, Hostetter TH. Pathophysiology of chronic tubulo-interstitial disease in rats. Interactions of dietary acid load, ammonia, and complement component C3. J Clin Invest 1985; 76: 667-75.

39. Ng HY, Chen HC, Tsai YC, Yang YK, Lee CT. Activation of intrarenal renin-angiotensin system during metabolic acidosis. Am J Nephrol 2011; 34: 55-63.

40. Atkins JL. Effect of sodium bicarbonate preloading on ischemic renal failure. Nephron 1986; 44: 70-4.

41. Bailey M, McGuinness S, Haase M, Haase-Fielitz A, Parke R, Hodgson CL, et al. Sodium bicarbonate and renal function after cardiac surgery: a prospectively planned individual patient meta-analysis. Anesthesiology 2015; 122: 294-306.

42. Tian ML, Hu Y, Yuan J, Zha Y. Efficacy and safety of perioperative sodium bicarbonate therapy for cardiac surgery-associated acute kidney injury: a meta-analysis. J Cardiovasc Pharmacol 2015; 65: 130-6.

43. Dalfino L, Tullo L, Donadio I, Malcangi V, Brienza N. Intra-abdominal hypertension and acute renal failure in critically ill patients. 
Intensive Care Med 2008; 34: 707-13.

44. Demarchi AC, de Almeida CT, Ponce D, e Castro MC, Danaga AR, Yamaguti FA, et al. Intra-abdominal pressure as a predictor of acute kidney injury in postoperative abdominal surgery. Ren Fail 2014; 36: 557-61.

45. De Waele JJ, De Laet I, Kirkpatrick AW, Hoste E. Intra-abdominal Hypertension and Abdominal Compartment Syndrome. Am J Kidney Dis 2011; 57: 159-69.

46. Roberts DJ, Ball CG, Kirkpatrick AW. Increased pressure within the abdominal compartment: intra-abdominal hypertension and the abdominal compartment syndrome. Curr Opin Crit Care 2016; 22: 174-85.

47. Sugrue M. Abdominal compartment syndrome and the open abdomen: any unresolved issues? Curr Opin Crit Care 2017; 23 : 73-8.

48. Dunn MD, McDougall EM. Renal physiology. Laparoscopic considerations. Urol Clin North Am 2000; 27: 609-14.

49. Hawasli A, Oh H, Schervish E, Frontera R, Gonsherova I, Khoury H. The effect of pneumoperitoneum on kidney function in laparoscopic donor nephrectomy. Am Surg 2003; 69: 300-3.

50. Nguyen NT, Perez RV, Fleming N, Rivers R, Wolfe BM. Effect of prolonged pneumoperitoneum on intraoperative urine output during laparoscopic gastric bypass. J Am Coll Surg 2002; 195: 476-83.

51. Karkouti K, Wijeysundera DN, Yau TM, Callum JL, Cheng DC, Crowther M, et al. Acute kidney injury after cardiac surgery: focus on modifiable risk factors. Circulation 2009; 119: 495-502.

52. Vives M, Wijeysundera D, Marczin N, Monedero P, Rao V. Cardiac surgery-associated acute kidney injury. Interact Cardiovasc Thorac Surg 2014; $18: 637-45$.

53. Grayson AD, Khater M, Jackson M, Fox MA. Valvular heart operation is an independent risk factor for acute renal failure. Ann Thorac Surg 2003; 75: 1829-35.

54. Lapi F, Azoulay L, Yin H, Nessim SJ, Suissa S. Concurrent use of diuretics, angiotensin converting enzyme inhibitors, and angiotensin receptor blockers with non-steroidal anti-inflammatory drugs and risk of acute kidney injury: nested case-control study. BMJ 2013; 346 : e8525.

55. Mårtensson J, Bellomo R. Prevention of renal dysfunction in postoperative elderly patients. Curr Opin Crit Care 2014; 20 : 451-9.

56. Garcia S, Ko B, Adabag S. Contrast-induced nephropathy and risk of acute kidney injury and mortality after cardiac operations. Ann Thorac Surg 2012; 94: 772-6.

57. McCullough PA. Contrast-induced acute kidney injury. J Am Coll Cardiol 2008; 51: 1419-28.

58. Pisani A, Riccio E, Andreucci M, Faga T, Ashour M, Di Nuzzi A, et al. Role of reactive oxygen species in pathogenesis of radiocontrastinduced nephropathy. Biomed Res Int 2013; 2013: 868321.

59. Mori K, Nakao K. Neutrophil gelatinase-associated lipocalin as the real-time indicator of active kidney damage. Kidney Int 2007; 71: 96770.

60. Mishra J, Ma Q, Prada A, Mitsnefes M, Zahedi K, Yang J, et al. Identification of neutrophil gelatinase-associated lipocalin as a novel early urinary biomarker for ischemic renal injury. J Am Soc Nephrol 2003; 14: 2534-43.

61. Mishra J, Dent C, Tarabishi R, Mitsnefes MM, Ma Q, Kelly C, et al. Neutrophil gelatinase-associated lipocalin (NGAL) as a biomarker for acute renal injury after cardiac surgery. Lancet 2005; 365: 1231-8.

62. Koyner JL, Parikh CR. Clinical utility of biomarkers of AKI in cardiac surgery and critical illness. Clin J Am Soc Nephrol 2013; 8: 1034-42.

63. Dai X, Zeng Z, Fu C, Zhang S, Cai Y, Chen Z. Diagnostic value of neutrophil gelatinase-associated lipocalin, cystatin C, and soluble triggering receptor expressed on myeloid cells-1 in critically ill patients with sepsis-associated acute kidney injury. Crit Care 2015; $19: 223$.

64. Nejat M, Pickering JW, Walker RJ, Westhuyzen J, Shaw GM, Frampton CM, et al. Urinary cystatin C is diagnostic of acute kidney injury and sepsis, and predicts mortality in the intensive care unit. Crit Care 2010; 14: R85.

65. Sabbisetti VS, Waikar SS, Antoine DJ, Smiles A, Wang C, Ravisankar A, et al. Blood kidney injury molecule-1 is a biomarker of acute and chronic kidney injury and predicts progression to ESRD in type I diabetes. J Am Soc Nephrol 2014; 25: 2177-86.

66. Han WK, Wagener G, Zhu Y, Wang S, Lee HT. Urinary biomarkers in the early detection of acute kidney injury after cardiac surgery. Clin J Am Soc Nephrol 2009; 4: 873-82.

67. Gocze I, Koch M, Renner P, Zeman F, Graf BM, Dahlke MH, et al. Urinary biomarkers TIMP-2 and IGFBP7 early predict acute kidney injury after major surgery. PLoS One 2015; 10: e0120863.

68. Kashani K, Al-Khafaji A, Ardiles T, Artigas A, Bagshaw SM, Bell M, et al. Discovery and validation of cell cycle arrest biomarkers in human acute kidney injury. Crit Care 2013; 17: R25.

69. Meersch M, Schmidt C, Van Aken H, Martens S, Rossaint J, Singbartl K, et al. Urinary TIMP-2 and IGFBP7 as early biomarkers of acute kidney injury and renal recovery following cardiac surgery. PLoS One 2014; 9: e93460.

70. Brienza N, Giglio MT, Marucci M, Fiore T. Does perioperative hemodynamic optimization protect renal function in surgical patients? A meta-analytic study. Crit Care Med 2009; 37: 2079-90.

71. Walsh M, Devereaux PJ, Garg AX, Kurz A, Turan A, Rodseth RN, et al. Relationship between intraoperative mean arterial pressure and clinical outcomes after noncardiac surgery: toward an empirical definition of hypotension. Anesthesiology 2013; 119: 507-15.

72. Prowle JR, Kirwan CJ, Bellomo R. Fluid management for the prevention and attenuation of acute kidney injury. Nat Rev Nephrol 2014; 10: $37-47$.

73. Enghard P, Rademacher S, Nee J, Hasper D, Engert U, Jörres A, et al. Simplified lung ultrasound protocol shows excellent prediction of 
extravascular lung water in ventilated intensive care patients. Crit Care 2015; 19: 36.

74. Hur E, Usta M, Toz H, Asci G, Wabel P, Kahvecioglu S, et al. Effect of fluid management guided by bioimpedance spectroscopy on cardiovascular parameters in hemodialysis patients: a randomized controlled trial. Am J Kidney Dis 2013; 61: 957-65.

75. Wilcox CS. Regulation of renal blood flow by plasma chloride. J Clin Invest 1983; 71: 726-35.

76. Chowdhury AH, Cox EF, Francis ST, Lobo DN. A randomized, controlled, double-blind crossover study on the effects of 2-L infusions of 0.9\% saline and plasma-lyte ${ }^{\triangleright} 148$ on renal blood flow velocity and renal cortical tissue perfusion in healthy volunteers. Ann Surg 2012; 256: 1824.

77. Rosenberger C, Rosen S, Heyman SN. Renal parenchymal oxygenation and hypoxia adaptation in acute kidney injury. Clin Exp Pharmacol Physiol 2006; 33: 980-8.

78. Walsh M, Garg AX, Devereaux PJ, Argalious M, Honar H, Sessler DI. The association between perioperative hemoglobin and acute kidney injury in patients having noncardiac surgery. Anesth Analg 2013; 117: 924-31.

79. Karkouti K, Grocott HP, Hall R, Jessen ME, Kruger C, Lerner AB, et al. Interrelationship of preoperative anemia, intraoperative anemia, and red blood cell transfusion as potentially modifiable risk factors for acute kidney injury in cardiac surgery: a historical multicentre cohort study. Can J Anaesth 2015; 62: 377-84.

80. Habib RH, Zacharias A, Schwann TA, Riordan CJ, Engoren M, Durham SJ, et al. Role of hemodilutional anemia and transfusion during cardiopulmonary bypass in renal injury after coronary revascularization: implications on operative outcome. Crit Care Med 2005; 33: 174956.

81. O'Keeffe SD, Davenport DL, Minion DJ, Sorial EE, Endean ED, Xenos ES. Blood transfusion is associated with increased morbidity and mortality after lower extremity revascularization. J Vasc Surg 2010; 51: 616-21.

82. Goodnough LT, Shander A. Patient blood management. Anesthesiology 2012; 116: 1367-76.

83. Ho KM, Power BM. Benefits and risks of furosemide in acute kidney injury. Anaesthesia 2010; 65: 283-93.

84. Bent P, Tan HK, Bellomo R, Buckmaster J, Doolan L, Hart G, et al. Early and intensive continuous hemofiltration for severe renal failure after cardiac surgery. Ann Thorac Surg 2001; 71: 832-7.

85. Schiffl H, Lang SM, Fischer R. Daily hemodialysis and the outcome of acute renal failure. N Engl J Med 2002; 346: 305-10. 